\title{
Public Procurement as a Tool to Drive Innovation in South Africa
}

\section{P Bolton*}

\section{P.E.R}

Pioneer in peer-reviewed, open access online law publications.

Authors

Phoebe Bolton

Affiliation

University of Stellenbosch

Email pbolton@sun.ac.za

Date published

12 December 2016

Editor Dr A Gildenhuys

How to cite this article

Bolton P "Public Procurement as a Tool to Drive Innovation in South Africa" PER / PELJ 2016(19) - DOI http://dx.doi.org/10.17159/17273781/2016/v19i0a1286

\section{Copyright}

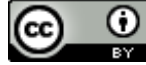

DOI

http://dx.doi.org/10.17159/1727-

3781/2016/v19i0a1286

\begin{abstract}
This article is an analysis of the use of public procurement as a tool to drive innovation. It explores the meaning of innovative procurement or public procurement of innovation, as well as the rationale for using public procurement to drive innovation. It then focuses on South Africa and evaluates whether there is scope within the existing public procurement regulatory regime for the promotion of innovation. Barriers in the regime are identified and suggestions are made for possible reform.
\end{abstract}

\section{Keywords}

Constitution; contracts; government; innovation; policy promotion; preferential procurement; public procurement; tenders. 


\section{Introduction}

In recent years the use of public procurement as a tool to drive innovation ${ }^{1}$ has received growing attention internationally. ${ }^{2}$ This use of procurement is referred to inter alia as public procurement of innovation (PPI), public procurement for innovation (PPfl), innovation-friendly procurement, innovative procurement and (in earlier years) public technology procurement. The new 2014 European Union Directives on public contracts, in particular, make extensive provision for the use of procurement as a tool to drive innovation and introduce a new "innovation partnership" procedure. ${ }^{3}$ In essence, the idea is that EU suppliers will tender to enter into a partnership with a procuring entity with the aim of developing a new product or service (including works, a system or a process). Ultimately, the procurement of innovative products and services is considered vital for improving the quality and efficiency of public services and to address important socio-economic challenges. The 2011 UNCITRAL Model Law on Public Procurement also provides for new procurement procedures that are aimed at facilitating dialogue between procuring entities and suppliers with a view to procuring innovative

* Phoebe Bolton. BProc LLB (cum laude) LLM LLD (UWC). Professor of Public Procurement Law, Stellenbosch University, South Africa. E-mail: pbolton@sun.ac.za. This research was funded by the National Research Foundation.

1 The term "innovation" as used here refers to the procurement of new or substantially new products or services and not to how the procurement process is conducted and the manner in which the procedures employed can be more innovative.

2 See generally Lember, Kattel and Kalvet Public Procurement; Angel and Blay 2014 Eur Procurement \& Pub Private Partnership L Rev 3-11; Rolfstam Public Procurement and Innovation; Georghiou et al 2010 https://www.escholar.manchester.ac.uk/

api/datastream?publicationPid=uk-ac-man-scw:217123\&datastreamld=FULL-

TEXT.PDF; Kattel and Lember 2010 http://hum.ttu.ee/wp/paper31.pdf; Hommen and Rolfstam 2009 JOPP 17-56; OECD Demand-side Innovation Policies; Edquist and Zabala-Iturriagagoitia 2012 Research Policy 1757-1769.

3 The new EU directives were approved by the European Parliament on 15 January 2014. The old EU Directives 2004/17 and 2004/18 were replaced with three new directives, two of which deal with "classic" and "utilities" public procurement and the third with concession contracts. See Directive 2014/24/EU of the European Parliament and of the Council of 26 February 2014 on Public Procurement and Repealing Directive 2004/18/EC (the new 2014 EU Public Procurement Directive); Directive 2014/25/EU of the European Parliament and of the Council of 26 February 2014 on Procurement by Entities operating in the Water, Energy, Transport and Postal Services Sectors and Repealing Directive 2004/17/EC (the new 2014 EU Public Utilities Directive); and Directive 2014/23/EU of the European Parliament and of the Council of 26 February 2014 on the Award of Concession Contracts (the new 2014 EU Concessions Directive). 
products. ${ }^{4}$ The Organisation for Economic Cooperation and Development (OECD) further claims that innovative procurement: ${ }^{5}$

\begin{abstract}
... has proven to be an effective measure in many countries and suggests for developed as well as developing countries to introduce their own [innovative procurement] policies as part of the demand-side innovation policy mix. Moreover, [the] OECD is of the opinion that [innovative procurement] related programs, even in developed countries, must be accelerated and expanded "wherever possible".
\end{abstract}

The use of public procurement to drive innovation has also picked up momentum in countries such as Canada, China, New Zealand, India and Japan. ${ }^{6}$ The aim of this paper is to explore the use of public procurement to drive innovation in South Africa and to determine whether there is scope within the existing legal framework for such use. The paper will be confined, in the main, to an analysis of section 217 of the Constitution of the Republic of South Africa, 1996 (the Constitution), the Preferential Procurement Policy Framework Act (PPPFA) ${ }^{7}$ that has been enacted to give effect to section 217(3) of the Constitution, and the Regulations that have been promulgated under this Act. $^{8}$ Where relevant, reference will also be made to other procurement-specific legislation and policy documents. An analysis of the role that innovation plays or could potentially play in the construction and defense industries falls outside the scope of this paper. The paper will also not enquire into the role that innovation plays or could potentially play in the public-private partnership (PPP) context.

First, attention will be given to the meaning of innovative procurement or public procurement of innovation, as well as the rationale for using public procurement to drive innovation. The focus will then shift to the role (if any) that innovative procurement currently plays and can potentially play in the South African context. Barriers in the regulatory regime will be identified and suggestions will be made on how the existing barriers could potentially be addressed.

4 The UNCITRAL Model Law on Public Procurement (2011) is a framework law and was adopted as a template for developing and reforming regulatory systems for public procurement. It has proven to be very successful and has formed the basis of procurement law in more than 30 countries across the world. See Arrowsmith and Nicholas "UNCITRAL Model Law on Procurement" ch 1.

5 Kattel and Lember 2010 http://hum.ttu.ee/wp/paper31.pdf 4 - referring to OECD Reviews of Innovation Policy 9.

$6 \quad$ See Rolfstam Public Procurement and Innovation 1 and the sources referred to there.

7 Preferential Procurement Policy Framework Act 5 of 2000 (the PPPFA).

8 GN 502 in GG 34350 of 8 June 2011 (Preferential Procurement Regulations). 


\section{Public procurement of innovation: meaning and rationale}

The term "public procurement" generally refers to the purchase of goods and services by government or public entities to fulfil their various functions. Value for money or procurement on the best possible terms is usually considered of primary importance in this purchasing exercise, but for many years the purchasing power of governments has been used to achieve secondary, collateral or horizontal policies as well. ${ }^{9}$ Over the years the range of public policies that public procurement can promote has also broadened. Not too long ago the use of public procurement to protect the environment was at the forefront, and more recently the use of public procurement to stimulate innovation is receiving growing attention. The purchasing power of governments is being recognised as a demand-sideoriented tool that can influence and stimulate innovation. It is being recognised, in particular, for the key role that it can play to drive innovation in areas that are generally the preserve of the public sector such as health services, education, energy, transport and firefighting.

In essence, "innovative procurement" or "PPI" refers to the purchase of a good that is not yet in existence or that is in existence but whose design and production will require further, if not completely new technological development, for example by means of research and development (R\&D). A possible reason for this may be to enable the government to obtain a cheaper or more cost-effective good. The accepted view is that innovative products and services reflect higher quality and / or more competitive prices and will generally optimise public service operation by integrating new processes, technologies or materials. ${ }^{10}$ The idea, therefore, is for governments to encourage suppliers to develop their capacity for innovation. As the largest purchaser of goods and services in a country, governments can serve as the lead customer or first client of innovative products and can foster and accelerate access to the market for innovative solutions.

$9 \quad$ See generally Caranta and Trybus Green and Social Procurement; Arrowsmith and Kunzlik Social and Environmental Policies; McCrudden Buying Social Justice. On Africa, see Bolton Government Procurement in South Africa ch 10 and Quinot "Promotion of Social Policy" ch 15.

10 See the summary on how the new 2014 EU Directives incorporate innovation in Fact Sheet 9 - EU 2014 http://ec.europa.eu/internal_market/publicprocurement/ docs/modernising_rules/reform/fact-sheets/fact-sheet-09-innovation_en.pdf. 
It seems important here to highlight that there is a difference between innovative procurement and what can be referred to as "regular procurement" or "conventional procurement". The latter would refer to the purchase of ready-made products or off-the-shelf items like pens and paper that do not involve R\&D. There is, in other words, no innovation involved and it is usually only the price and the quality of the product that is taken into account when choosing a winning bidder. ${ }^{11}$ When engaging in "innovative procurement", however, price in itself would be viewed more holistically. Procurement procedures would take into account the total lifecycle cost of purchases when evaluating tenders. Innovative tenders may, in other words, be awarded more points given their long-term financial benefits. With innovative procurement, suppliers would also be allowed to tender variants with the aim of proposing the best solutions to meet the needs of the procuring entity. ${ }^{12}$ When using procurement to drive innovation, therefore, procuring entities should avoid restrictions on innovation, especially when use is made of labels when drafting tender specifications. ${ }^{13}$ Overly detailed specifications, for example, may limit the ability and creativity of potential suppliers to offer innovative solutions. To avoid different interpretations of the concept of "innovation" in the EU member states, the EU Public Procurement Directive, for example, defines the term "innovation" as:

the implementation of a new or significantly improved good, service or process, including but not limited to production, building or construction processes, a new marketing method, or a new organizational method in business practices, workplace organization or external relations inter alia with the purpose of helping to solve societal challenges or to support the Europe 2020 strategy for smart, sustainable and inclusive growth. ${ }^{14}$

Public Procurement as a tool to drive innovation can further be categorized as either direct or general, or specific or catalytic. ${ }^{15}$ Direct or general PPI refers to a situation where the procuring entity is also the enduser of the product that is procured. The procuring entity, in other words, simply uses its own demand or need to stimulate or encourage innovation. The resulting innovation is, however, often also spread to other users and can thus be beneficial for the procuring entity as well as society as a

11 In the South African context, and as will be explained in more detail below, "equity" or "preference" also plays a role in the award of public contracts.

12 See for example Recital 48 and art 45 of the new 2014 EU Public Procurement Directive.

13 Angel and Blay 2014 Eur Procurement \& Pub Private Partnership L Rev 4-5.

14 Article 2(1)(22) in the "Scope, Definitions and General Principles" section of the new 2014 EU Procurement Directive. For an analysis of this definition, see Angel and Blay 2014 Eur Procurement \& Pub Private Partnership L Rev 5-6.

15 See Edquist and Zabala-Iturriagagoitia 2012 Research Policy 1757. 
whole. ${ }^{16}$ Specific or catalytic PPI refers to a situation where the procuring entity "serves as a catalyst, coordinator and technical resource for the benefit of end-users". ${ }^{17}$ The need or demand is, in other words, found outside the procuring entity, who procures the new products not for itself, ie for its own mission requirements, but for others. Direct and catalytic procurement is thus tied to the user of the resulting product. Direct procurement is often related to infrastructure development ${ }^{18}$ or to support the missions of the procuring entity itself. ${ }^{19}$ Catalytic procurement on the other hand is used to support "infant" products or industries and is meant to serve private demand. ${ }^{20}$

PPI can also be categorised with reference to the character of the result of the procurement process; in other words, the character of the innovation which is embedded in the resulting product. ${ }^{21}$ In this sense, PPI can either be adaptive or developmental. Adaptive PPI is "when the product or system procured is incremental and new only to the country (or region) of procurement". ${ }^{22}$ Innovation is therefore required to adapt the product to the specific national or local conditions. Developmental PPI on the other hand implies that "completely new to the world" products or systems are created as a result of the procurement process. ${ }^{23}$ It can thus be referred to as "creation oriented" PPI and involves radical innovation. ${ }^{24}$ It is important to note, however, that examples of the implementation of the public procurement of innovation in a number of EU member states shows that incremental innovations feature most often, and not radical innovations. The possibilities for the procurement of radical innovations occur only on very rare occasions in practice..$^{25}$

16 Edquist and Zabala-Iturriagagoitia 2012 Research Policy 1758-1759.

17 Edquist and Zabala-Iturriagagoitia 2012 Research Policy 1759.

18 For example the procurement of the X2000 high-speed train in Sweden, where the Swedish State Railway Company was the user and the major social need was human mobility (transport).

19 An example here is the US Federal Aviation Administration, which procured an "Automatic Dependent Surveilance-Broadcast System" to replace existing groundbased radars.

20 For example Sweden's light corridor project which was aimed at increasing energy efficiency. See further Edquist and Zabala-Iturriagagoitia 2012 Research Policy 1757, 1760, 1763, 1765.

21 Edquist and Zabala-Iturriagagoitia 2012 Research Policy 1763.

22 Edquist and Zabala-Iturriagagoitia 2012 Research Policy 1759.

23 Edquist and Zabala-Iturriagagoitia 2012 Research Policy 1759.

24 Edquist and Zabala-Iturriagagoitia 2012 Research Policy 1759.

25 For an overview of public procurement of innovation in a number of EU member countries, see EU Project OMC-PTP 2009 http://de.koinnobmwi.de/system/publications/files/000/000/040/original/Exploring_public_procureme nt_as_a_Strategic_Innovation_Policy_Mix_Instrument.pdf?1372758315 65-73. 
A typical PPI process may include the following stages:

1. The identification of a "grand" need or challenge and its formulation in terms of a lack of satisfaction of a human need or an unsolved societal problem.

2. The translation of the identified need or challenge into functional specifications. ${ }^{26}$

3. A tendering process that entails the opening of a competition by means of a tender process; the translation of the functional specifications into technical specifications by potential suppliers; and the submission of formal tenders by potential suppliers.

4. The evaluation of tenders and the awarding of contracts.

5. The delivery process, which includes product development, the production of the product, and final delivery to the procuring entity. ${ }^{27}$

During the above stages there will also be extensive dialogue or "cooperation" between the procuring entity and suppliers, which distinguishes the PPI process from the regular or conventional tender process. ${ }^{28}$ In the conventional tender process, detailed specifications are drafted by the procuring entity and there is, as a rule, no or very little dialogue between the procuring entity and interested suppliers, which accordingly makes this procedure generally unsuitable for the procurement of innovative products.

To sum up, therefore, public procurement of innovation can be justified on a number of grounds. As the provider of goods and services such as infrastructure, public information and defence, etcetera governments can ensure the provision of better or at least more efficient public services by making use of innovative technologies. ${ }^{29}$ There are a number of specific areas, such as the health sector, that could benefit from innovative

26 The term "functional specifications" as used here would refer for example to the expected outcome or end result of the procurement process. In contrast, the term "technical specifications" would refer to how the end result of the procurement process will be or should be achieved.

27 Edquist and Zabala-Iturriagagoitia 2012 Research Policy 1757, 1759.

28 See the case studies discussed by Edquist and Zabala-Iturriagagoitia 2012 Research Policy 1757, 1760-1766.

29 OECD Demand-side Innovation Policies 37. 
technology. ${ }^{30}$ Innovative procurement practices can potentially result in cost savings for the government and also create opportunities for employment. 31

Lastly, it is important to note that innovative procurement or the procurement of innovation (as referred to in this paper) should not be confused with "innovation in procurement". The latter would refer for example to the use of electronic procurement and new procedures or procurement methods, such as the competitive dialogue procedure that was introduced at EU level in 2004. When focusing in paragraph 3 below on the position in South Africa and in particular the different ways in which current obstacles to the use of procurement to drive innovation may be addressed, reference will be made to the potential use of a new procurement procedure, ${ }^{32}$ but this does not detract from the fact that this paper is concerned with "innovative procurement", ie the procurement of innovation which involves the purchase of products or services that are new or substantially new and whose development usually involves significant R\&D expenditure. In some instances, however, an innovative procurement process can assist in the procurement of innovative products and services.

\section{South Africa's regulatory regime ${ }^{33}$}

The size of public procurement in South Africa is estimated to be around $22 \%$ of gross domestic product (GDP), ${ }^{34}$ and the most recent annual procurement spend is in the region of R500bn. ${ }^{35}$ Given its economic and political importance, this function of the government is extensively regulated. Most importantly, public procurement is constitutionalised. Section 217(1) of the Constitution requires procuring entities to procure goods and services in a manner that is fair, equitable, transparent,

30 EU Project OMC-PTP 2009 http://de.koinno-bmwi.de/system/publications/files/000/ 000/040/original/Exploring_public_procurement_as_a_Strategic_Innovation_Policy_ Mix_Instrument.pdf?1372758315.

31 For the state of unemployment on the African continent, see AFP 2013 http://www.news24.com/Africa/News/Africas-unemployment-figures-frightening20131121. For unemployment figures in South Africa, see Trading Economics 2016 http://www.tradingeconomics.com/south-africa/unemployment-rate.

32 See, in particular, para 3.2.2 below.

33 For an in-depth analysis, see Bolton Government Procurement in South Africa and for more recent work, see Bolton "Regulatory Framework for Public Procurement" ch 9. Also see Penfold and Reyburn "Public Procurement" ch 25 and De la Harpe Public Procurement Law.

34 Audet 2002 OECD Journal on Budgeting 180.

35 Scott 2016 http://www.cips.org/supply-management/news/2016/february/southafrica-to-reform-public-procurement-processes/. 
competitive and cost-effective. ${ }^{36}$ Provision is also made, however, for the use of procurement for horizontal purposes. Procuring entities are allowed to implement procurement policies that provide for "categories of preference in the allocation of contracts"37 and "the protection or advancement of persons or categories of persons disadvantaged by unfair discrimination". ${ }^{38}$ This horizontal use of procurement must comply with a national legislative framework, however. The Preferential Procurement Policy Framework Act (PPPFA) ${ }^{39}$ was enacted in 2000 to provide a framework for the implementation of preferential procurement policies and revised Regulations to the Act were released in 2011.40 The Regulations were revised, inter alia, to bring them more in line with South Africa's Broad-Based Black Economic Empowerment Act, ${ }^{41}$ enacted in 2003. The aim of the latter Act is, inter alia, to establish a legislative framework for the promotion of black economic empowerment (BEE) in South Africa. ${ }^{42}$

Aside from the procurement clause in the Constitution (section 217) and the PPPFA and its Regulations, there is also a wide array of legislation and policy documents that regulate the procurement practices of procuring entities. Of particular importance are the Public Finance Management Act (PFMA) ${ }^{43}$ and its Supply Chain Management Regulations (PFMA SCM Regulations) ${ }^{44}$ which regulate financial matters and more specifically procurement practices at national and provincial government level. At local government level, the Local Government: Municipal Finance Management Act (MFMA) ${ }^{45}$ and its Supply Chain Management Regulations (MFMA SCM Regulations) ${ }^{46}$ find application. From an organisational point of view, the National Treasury is tasked with overseeing government expenditure and thus also procurement. ${ }^{47}$

36 The term "procuring entities" as used here refers in broad terms to government or public entities such as departments, municipalities and state-owned enterprises (like ESKOM, TELKOM and TRANSNET).

37 Section $217(2)(\mathrm{a})$ of the Constitution.

38 Section $217(2)(\mathrm{b})$ of the Constitution.

39 Preferential Procurement Policy Framework Act 5 of 2000 (the PPPFA).

40 GN 502 in GG 34350 of 8 June 2011 (Preferential Procurement Regulations).

41 Broad-Based Black Economic Empowerment Act 53 of 2003.

42 See the Preamble to the Broad-Based Black Economic Empowerment Act 53 of 2003.

43 Public Finance Management Act 1 of 1999.

44 GN 225 in GG 27388 of 15 March 2005 (Treasury Regulations for Departments, Trading Entities, Constitutional Entities and Public Entities) - see in particular Regulation 16.

45 Local Government: Municipal Finance Management Act 56 of 2003 (the MFMA).

46 Gen N 868 in GG 27636 of 30 May 2005 (Municipal Finance Management Act, 2003: Municipal Supply Chain Management Regulations).

47 See National Treasury 2016 http://www.treasury.gov.za. 
As seen, section 217 of the Constitution mandates the use of procurement for horizontal purposes. Thus far, this use has been confined primarily to addressing past apartheid policies and practices. ${ }^{48}$ For the purposes of this paper, however, it will be important to determine whether section 217 provides scope also for the use of procurement to drive innovation. It will also be necessary to analyse the PPPFA and its Regulations since this is the legislation that provides a national framework for the implementation of horizontal policies. In particular, attention will be given to certain key stages in the procurement process to determine whether the current legislative regime leaves scope for the incorporation of innovation. Barriers to the use of procurement to drive innovation will be identified and suggestions will be made on how these barriers could potentially be addressed.

\subsection{Section 217 of the Constitution}

On a reading of section 217 , it is clear that using procurement as a means to address past apartheid injustices is of the utmost importance. This is clear from section $217(2)$ (b) in particular, which allows procuring entities to implement procurement policies that provide for "the protection or advancement of persons or categories of persons disadvantaged by unfair discrimination". Of importance, however, is that section 217(2)(a) speaks of a much broader use of procurement for horizontal purposes; it provides (simply) for the implementation of a procurement policy providing for "categories of preference in the allocation of contracts". It is clear, therefore, that in the same way that the protection of the environment could, for example, be read into section $217(2)(a)$ of the Constitution, ${ }^{49}$ the use of procurement to drive innovation could similarly be read into this provision. Section 217(2)(a) leaves scope for procuring entities to incorporate environmental considerations into the procurement process and in the same way it can be argued that section $217(2)(a)$ leaves scope for procuring entities to incorporate innovation-related criteria into the procurement process.

A few years ago, for example, the government introduced a "reservation scheme". This was done in terms of Regulation 9 of the 2011 PPPFA Regulations, which allow procuring entities to give preference to "locally produced goods, services or works or locally manufactured goods, with a stipulated minimum threshold for local production and content". The

48 See, for example, Quinot "Promotion of Social Policy" 467; Bolton and Quinot "Social Policies in Procurement" ch 16; Bolton 2004 SALJ 619-635.

49

See Bolton 2008 TSAR 39. 
Department of Trade and Industry subsequently designated industries, sectors and sub-sectors for local production at a specified level of local content. ${ }^{50}$ Certain contracts are, in other words, reserved for local production with minimum local content thresholds. It is clear that this reservation scheme falls neatly under section 217 (2)(a) of the Constitution, which as noted above provides simply for "categories of preference in the allocation of contracts". In a similar fashion, therefore, section 217(1)(a) provides scope for the incorporation of innovation-related criteria in the procurement process.

Having determined that section 217 of the Constitution provides scope for the use of procurement to drive innovation, it needs to be determined whether scope is provided also in the legislation. Barriers in the legislation will be identified and possible solutions will be offered.

\subsection{The legislative regime: barriers and possible solutions}

As noted, the PPPFA and Regulations provide a national framework for the implementation of preferential procurement policies. In particular, section 2(1)(d) of the PPPFA deals with the goals that "may" be pursued by means of preferential procurement policies. Of importance is that this provision, by using the word "may" (as opposed to "must") is drafted in broad terms. The goals for which preferential procurement "may" be used are not restricted to the goals specifically mentioned, ie contracting with persons or categories of persons historically disadvantaged by unfair discrimination on the basis of race, gender or disability; and implementing the programmes of the Reconstruction and Development Programme. Section 5(1) of the PPPFA further provides that "[t]he Minister [of Finance] may make regulations regarding any matter that may be necessary or expedient to prescribe in order to achieve the objects of this Act". The Minister is thus given the authority to promote innovation in procurement. There is, in other words, scope in the PPPFA for the use of procurement to drive innovation.

In what follows, specific attention will be given to the role (if any) that innovation currently plays in the PPPFA and Regulations. Where relevant, attention will also be given to other procurement-specific legislation and government documents. The three main stages of the procurement process will be analysed, ie the planning stage, the evaluation and award stage, and the contract performance stage. In particular, the focus will be

50 More information on the reservation scheme is available at dti 2016 http://www.dti.gov.za/industrial_development/ip.jsp. 
on the following key events: (1) the determination of a need and the communication of that need to suppliers; (2) procurement procedures or methods of procurement and whether these are conducive to the use of procurement to drive innovation; (3) the consideration of unsolicited offers; (4) the evaluation of quality or functionality; (5) award criteria; and (6) contract performance conditions. Barriers that currently hinder the promotion of innovation will be highlighted and suggestions will be made on how these could potentially be addressed.

\subsubsection{The determination of a need and communicating such need to suppliers}

To promote innovation a procuring entity would, during the planning stage, have to identify the need for an innovative product or service that cannot be met through buying goods or services already available in the market. The procuring entity would further have to stipulate the expected outcome or end result of the procurement process and not how the end result of the procurement process will be or should be achieved. The procuring entity would, in other words, have to make use of "functional specifications" as opposed to "technical specifications" when communicating its need to potential suppliers. ${ }^{51}$ Thus, the procuring entity must not be too descriptive; it must "[not] over-specify - as this can kill innovation". ${ }^{52}$ Also, in those instances where a procuring entity must be specific, it should still provide suppliers with the scope to offer variants, ie offers that propose a different approach to those suggested by the procuring entity.

Insofar as could be determined, no express provision is made in the legislation for the procurement of innovative goods or services. The legislation also does not expressly encourage procuring entities to do so. The legislation moreover simply refers to the term "specifications". 53 In other words, no distinction is drawn between "technical specifications" and "functional specifications". The MFMA SCM Regulations do, however, note that specifications must "where possible be described in terms of performance required rather than in terms of descriptive characteristics for design". ${ }^{54}$ Limited scope is therefore provided for innovative procurement. Of note is that the PFMA and SCM Regulations as well as the PPPFA and its Regulations are silent on the use of specifications.

\footnotetext{
51 Also see section 1 of the paper for further clarity on the difference between "functional specifications" and "technical specifications".

52 Semple date unknown https://www.innovation-procurement.org/fileadmin/editorcontent/Guides/PPI-Platform_Guide_new-final_download.pdf.

53 See for example MFMA SCM Regulation 27 and PFMA SCM Regulation 16A6.2(b).

54 MFMA SCM Regulation 27(2)(c).
} 
To identify the need for an innovative product or service and to subsequently evaluate offers received a procuring entity would clearly require the necessary expertise, or it would require the assistance of third parties, which may be quite costly. Given the monetary implications of using the assistance of third parties and moreover the lack of knowledge, skills and capacity of procurement personnel in South Africa, ${ }^{55}$ the identification of innovative needs may be particularly challenging in South Africa. Even in developed countries there is doubt as to the ability of procurement personnel to identify innovative needs and subsequently evaluate offers received. ${ }^{56}$

In the EU, provision is made for a "preliminary market consultation" with third parties prior to the identification of an innovative need. ${ }^{57}$ The parties consulted are then also likely to be future bidders. Provision is made, however, for how to guarantee that competition and equal treatment is not distorted, which goes some way in dispelling the concern that prior consultations with a future bidder will result in the award of the contract to such a bidder. What this signifies is that using procurement to drive innovation depends largely on communication with suppliers. This, once again, ties in with the need for procurement personnel in South Africa to have the necessary knowledge, skills and capacity.

\subsubsection{Procurement procedures or methods or procurement}

As noted in paragraph 2 above, an innovative procurement process can assist in the procurement of innovative products and services. In this respect, the current procurement procedures provided for in South Africa are not conducive to the promotion of innovation in procurement. A distinction is generally drawn between four types of procurement: petty cash purchases, verbal or written quotations, written price quotations and competitive bidding. ${ }^{58}$ The regulatory regime therefore provides in the main for standard procurement procedures. The general rule is that no negotiations may take place between procuring entities and bidders. Procuring entities are, as a rule, required to draft detailed specifications and must evaluate offers with reference to pre-determined specifications. ${ }^{59}$

\footnotetext{
55 For more on this, see para 3.3.1 below.

56 See Sanchez-Graells 2015 http://www.howtocrackanut.com/blog/2015/04/innovation-partnerships-under-reg31.html?rq=innovation\%20partnership.

57 See art 40 of the EU Public Procurement Directive.

58 Regulation 12(1) of the MFMA SCM Regulations; National Treasury Practice Note SCM 2.

59 For more on this, see generally Bolton 2006 Stell $L R$.
} 
The timescales for the existing procurement procedures are, moreover, around 21-30 days. ${ }^{60}$ This is too short a time frame for innovative procurement and to promote creative dialogue between the procuring entity and potential suppliers.

Provision is made, however, for exceptions to the prescribed use of the standard competitive bidding process. ${ }^{61}$ At local government level procuring entities may, for example, do away with competitive bidding procedures if doing so is impractical, as in the case of "emergencies" or a "sole supplier". 62 In such instances procurement may take place by other means such as price quotations or direct negotiations, provided that a record is kept of the reasons for deviating from an invitation for competitive bids and that such reasons are approved by the relevant authority. ${ }^{63}$ Similar rules apply at national and provincial government level. ${ }^{64}$ It would appear, therefore that limited scope is provided for the possible award of a contract to a sole supplier for innovation-related reasons. The award of such contracts is examined in greater detail in paragraph 3.2.3 below, where detailed attention is given to the consideration of unsolicited offers.

It is submitted that in order for there to be effective procurement of innovative goods and services, it is important for a specific procurement procedure to be in place that allows close contact between a procuring entity and the potential supplier(s). It is only this "close contact" that will make it possible for innovative procurement to take place. ${ }^{65}$ Interaction between the procuring entity and the supplier(s) is, in other words, of fundamental importance. It is submitted that the two-stage bidding process provided for at local government level ${ }^{66}$ could potentially be used for the procurement of innovation, provided of course express provision is also made for it in the legislation that applies to procuring entities at national

60 See PFMA SCM Regulation 16A6.3(c) and MFMA SCM Regulation 22(1)(b)(i) read with Regulation 22(2).

61 For national and provincial government level, see PFMA SCM Regulation 16A6.4 and National Treasury Practice Note SCM 2. For local government level, see MFMA SCM Regulation 36(1)(a).

62 Para 4.4 of National Treasury Practice Note SCM 2.

63 Para 4.4 of National Treasury Practice Note SCM 2.

64 See PFMA SCM Regulation 16A6.4. At local government level, procuring entities may also dispense with official procurement processes (including tender procedures) for "the acquisition of special works of art or historical objects where specifications are difficult to compile"; and for the acquisition of animals for zoos (MFMA SCM Regulations 36(1)(a)(iii) and 36(1)(a)(iv)).

65 Also see Georghiou et al 2010 https://www.escholar.manchester.ac.uk/api/ datastream?publicationPid=uk-ac-man-scw:217123\&datastreamld=FULL-TEXT.PDF 5 .

66 See MFMA SCM Regulation 25. 
and provincial government level. The two-stage bidding process at local government level is intended for large, complex projects; projects where it may be undesirable to prepare complete, detailed technical specifications; or long-term projects with a duration period exceeding three years. ${ }^{67}$ In the first stage, technical proposals on conceptual design or performance specifications should be invited, subject to technical as well as commercial clarifications and adjustments. In the second stage, final technical proposals and priced bids should be invited.

At present very little information is provided in the Regulations themselves on how precisely the two-stage bidding process is supposed to operate in practice. The National Treasury's Supply Chain Management Guide for Accounting Officers of Municipalities and Municipal Entities, ${ }^{68}$ however, provides guidance on the use of the procedure and in doing so does leave room for the use of the procedure to procure innovations. The process also appears to comply with the requirements in section 217 of the Constitution. It is nevertheless submitted that to combat possible abuse it is important for proper safeguards to be put in place when use is made of this procedure. In particular, provision should be made for records to be kept by procuring entities that specifically deal with two-stage bidding. Records should be required to reflect, inter alia, the following: the different occasions on which use was made of two-stage bidding; the reasons for having used two-stage bidding as opposed to a (single) call for tenders; the number of suppliers who were invited to submit proposals and the details of such proposals; the number and names of the suppliers who were ultimately invited to submit tenders; the details of the winning supplier's tender; and the reasons for its selection. ${ }^{69}$

An alternative to using the two-stage bidding process expressly provided for at local government level may be to introduce a completely new procurement procedure. Such a procedure could take the form of the "innovation partnership" procedure that is provided for in the new $2014 \mathrm{EU}$ Public Procurement Directive or the "request for proposals with dialogue" procedure introduced by the 2011 UNCITRAL Model Law on Public Procurement. ${ }^{70}$

\footnotetext{
MFMA SCM Regulation 25(1).

National Treasury 2005 http://mfma.treasury.gov.za/MFMA/Guidelines/ Guide\%20for\%20Municipal\%20Accounting\%200fficers_1.pdf.

Also see Bright Public Procurement Handbook 25.

See art 49 of the UNCITRAL Model Law on Public Procurement (2011).
} 
It is submitted that given that the UNCITRAL Model Law on Public Procurement is a framework law and is intended to be used by countries that are reforming their procurement systems, the "request for proposals with dialogue" procedure (as opposed to the "innovation partnership" procedure in the EU) may be a more suitable option. The procedure is designed for the procurement of relatively complex items and services and allows procuring entities to seek innovative solutions to technical issues, such as saving energy, achieving sustainable procurement or infrastructure needs, where there may be different technical solutions. ${ }^{71} \mathrm{~A}$ main condition for the use of this procedure is that it must not be objectively possible for the procuring entity to formulate a complete description of the subject matter of the procurement at the start of the procedure, and the procuring entity must foresee that it will need to engage in dialogue with suppliers in order to come to acceptable solutions to satisfy its needs. Other conditions for the use of the "request for proposals with dialogue" procedure include a prior failure of open tendering, and the procedure can be used for research and development or for the preservation of essential security interests. ${ }^{72}$

The request for proposals with dialogue procedure contained in the UNCITRAL Model Law would as a rule comply with the broad requirements contained in section 217(1) of the Constitution and is hence a potentially viable procedure that can be used to procure innovative goods and services in South Africa.

\subsubsection{Unsolicited offers}

As noted in paragraph 2 above, provision is made in the PFMA SCM Regulations and the MFMA SCM Regulations for exceptions to the prescribed use of the standard competitive bidding process. In particular, procurement may take place by other means, such as price quotations or direct negotiations if there is only one provider (a sole supplier) of the particular goods or services. Scope is thus provided for the award of a contract to a sole supplier for innovation-related reasons. The National Treasury has, by means of a Practice Note ${ }^{73}$ made provision for the consideration of unsolicited offers, i.e. offers that are received outside the normal procurement processes. In the Practice Note a number of requirements are laid down for the consideration of unsolicited offers by procuring entities, and one of these relates specifically to the innovative

\footnotetext{
Nicholas 2012 PPLR 117.

See art 30(2)(b)-(d) of the UNCITRAL Model Law on Public Procurement (2011).

National Treasury Practice Note 11.
} 
nature of the product or service. It is important, therefore, to analyse the Practice Note to determine how provision is made for the use of procurement to drive innovation.

On a reading of the Practice Note it is clear that a strict process is in place for the consideration of unsolicited offers. This is understandable given the nature of unsolicited offers (they are received outside a normal procurement process) and section $217(1)$ of the Constitution demands that procurement procedures be fair, equitable, transparent, competitive and cost-effective. The Practice Note makes clear that procuring entities are not under an obligation to consider unsolicited offers, but they may consider them if the following requirements are met:

(a) a comprehensive and relevant project feasibility study has established a clear business case; and

(b) the product or service involves an innovative design; or

(c) the product or service involves an innovative approach to project development and management; or

(d) the product or service presents a new and cost-effective method of service delivery. ${ }^{74}$

The Practice Note therefore clearly makes express provision for the consideration of offers that promote innovation. As noted, however, very strict procedures are in place. Amongst other things, the unsolicited offer must contain "a statement describing how the [offer] is demonstrably innovative and supported by evidence that the proponent is the sole provider of the innovation". ${ }^{75}$ An unsolicited offer will, for example, be unacceptable and must be rejected by the procuring entity if, amongst other things, it:

(a) relates to known institutional requirements that can, within reasonable and practicable limits, be acquired by conventional competitive bidding methods;

(b) relates to products or services which are generally available. ${ }^{76}$

If all the requirements for consideration are met and the procuring entity decides to consider the unsolicited offer, a registered letter must be sent to the proponent confirming the procuring entity's decision to consider the unsolicited offer. Moreover, if the unsolicited offer:

National Treasury Practice Note 11 para 2.1.

National Treasury Practice Note 11 para 2.3(c).

National Treasury Practice Note 11 paras 3.1(a) and (b). 
... complies with the requirement of existing unsolicited bid provisions in terms of the National Treasury issued circular entitled 'Implementation of Supply Chain Management' (dated 27 October 2004), namely the product or service is unique, innovative and provided by a sole provider, the [procuring entity] may enter into direct negotiation with the proponent, outside the normal competitive bidding process. ${ }^{77}$ [emphasis added]

In the case of other compliant unsolicited offers that are not of a PPP nature, ${ }^{78}$ a comprehensive evaluation of the offer must take place, which must include, inter alia, a feasibility study, whereafter an unsolicited proposal agreement must be concluded with the proponent. ${ }^{79}$ In essence, the unsolicited proposal agreement must make provision inter alia for:

(a) [t]he methodology for determining any costs to be reimbursed to the proponent, should the procurement processes set out [in the Practice Note] result in an award for the product or service being made to a party other than the proponent;

(b) the procedure for further developing the project and responding to issues raised by the institution;

(c) the allocation of responsibility for developing bid documents in accordance with the institution's supply chain management systems, provided that development of the document must always be under the supervision of the institution;

(d) the information in the unsolicited proposal must be treated as confidential; and

(e) the purchase of intellectual property rights, if any. ${ }^{80}$

Once the unsolicited proposal agreement is concluded, the procuring entity must prepare and issue bid documents. ${ }^{81}$ There must, in other words, be a procurement process. A Request for Qualification (RFQ) must be prepared, the aim of which is to test the market for the existence of other suppliers who are capable of providing the product or service. If there is no adequate response to the RFQ, a draft contract must be prepared. If, however, there is one of more adequate responses to the RFQ, a draft contract and a Request for Proposals (RFP) must be prepared. A competitive bidding process must then be conducted among the suppliers who qualified as well as the proponent who (initially)

77 National Treasury Practice Note 11 para 4.2.1.1.

78 As noted in para 1 above, this paper will not consider the role that innovation currently plays or could potentially play in the PPP context. The manner in which the Practice Note makes provision for compliant unsolicited offers in the PPP context will therefore not be analysed.

79 National Treasury Practice Note 11 para 4.2.3

80 National Treasury Practice Note 11 para 4.2.4.1.

81 National Treasury Practice Note 11 para 5. 
submitted the unsolicited offer. The proponent must be reimbursed if it is not ultimately awarded the contract. The Practice Note further makes clear that where use is made of independent consultants or experts to assist in the evaluation of unsolicited offers, such consultants or experts must undertake not to disclose any confidential material or information provided by the proponent of the unsolicited offer to unauthorised persons or entities. $^{82}$

The manner in which provision is made in the Practice Note for the consideration of unsolicited offers that involve innovation can be commended. Due regard is given to the requirements in section 217(1) of the Constitution to ensure, in particular, that the process aims to be transparent, competitive and fair. Provision is also made for the protection of confidential material and information provided by the proponent of the unsolicited offer. It is submitted, however, that to ensure compliance with the strict processes in the Practice Note for the consideration of unsolicited offers, it will be important for procurement personnel to have the necessary skills, knowledge and capacity. The current lack of skills and capacity of procurement personnel is likely to hinder the effective use of unsolicited offers to drive innovation. This is examined in greater detail in paragraph 3.3.1 below, where attention is given to non-legislative / general barriers that will impact on and hinder the use of procurement to drive innovation.

\title{
3.2.4 The evaluation of quality / functionality
}

The PPPFA Regulations make extensive provision for the role that quality (referred to as functionality in the Regulations) should play in the procurement process. ${ }^{83}$ Of importance is that functionality is defined as:

\begin{abstract}
the measurement according to predetermined norms, as set out in the tender documents, of a service or commodity that is designed to be practical and useful, working or operating, taking into account, among other factors, the quality, reliability, viability and durability of a service and the technical capacity and ability of a tenderer. ${ }^{84}$
\end{abstract}

This definition is relatively vague. ${ }^{85}$ It is generally accepted, however, that quality / functionality would refer to criteria such as the nature, quality, reliability, viability and durability of the product or service offered; the experience and track record of a supplier; the technical knowledge and

\footnotetext{
National Treasury Practice Note 11 para 6.1(a).

See Regulation 4 of the PPPFA Regulations.

Regulation 1(k) of the PPPFA Regulations. Emphasis added.

For comments on the definition, see Quinot 2014 PER/PELJ 1114.
} 
capacity of a supplier; the availability of tools or equipment for the supplier's use; the qualifications and competence of the personnel of a supplier; and the number of staff employed; etc. ${ }^{86}$ It is submitted that in the light of the fact that the phrase "among other factors" is included in the definition of "functionality", innovation-related criteria could potentially fall within the scope of the definition. Procuring entities could, in other words, list innovation-related criteria as functionality criteria.

The PPPFA Regulations make clear, however, that a procuring entity must first determine if functionality is relevant to the particular procurement. ${ }^{87}$ If so, suppliers must be informed that offers will be evaluated on the basis of functionality. ${ }^{88}$ The evaluation criteria for measuring functionality must be objective $^{89}$ and suppliers must be informed of the following: (1) the evaluation criteria for measuring functionality; (2) the weight of each criterion; (3) the applicable values; and (4) the minimum qualifying score for functionality. ${ }^{90}$ An offer must be regarded as acceptable only if it meets the minimum qualifying score for functionality ${ }^{91}$ and all offers that have achieved the minimum qualifying score for functionality must be evaluated further during the award stage. ${ }^{92}$

Innovation-related criteria can therefore potentially serve as functionality criteria under the PPPFA Regulations. The fixed way in which the functionality provisions are drafted, however, may serve as a hindrance to the effective use of innovation-related criteria as functionality criteria. In particular, the "minimum qualifying score" for functionality that suppliers must obtain may hinder innovation. With innovative products and services, suppliers should ideally be encouraged to strive for excellence as opposed to simply meeting minimum requirements. Those suppliers who exceed the stipulated minimum requirements are, moreover, not rewarded under the present regime. All suppliers who comply with the minimum score for functionality, and hence innovation-related criteria, must in terms of the Regulations be assessed equally thereafter, ie in the award stage. The only exception, as discussed in greater detail in paragraph 3.2.5 below, is where two suppliers score equal points during the award stage for both price and preference, in which case the contract must be awarded to the supplier who has the higher functionality score.

\footnotetext{
See further Bolton 2014 Speculum Juris 1-26.

Regulation 4 of the PPPFA Regulations.

Regulation 4(1) of the PPPFA Regulations.

Regulation 4(2) of the PPPFA Regulations.

Regulation 4(3) of the PPPFA Regulations.

Regulation 4(4) of the PPPFA Regulations.

Regulation 5 of the PPPFA Regulations.
} 
To circumvent the generally accepted meaning of a "minimum qualifying score" for functionality, for example that suppliers should score 80 out of 100 , it could be argued that a procuring entity may, for example, inform suppliers that the evaluation criteria for measuring functionality relate only to innovation-related criteria and that the overall minimum qualifying score is $100 \%$. Only suppliers who meet this score would then qualify for further evaluation during the award stage. Again, however, procurement personnel would require the necessary skills and expertise, which is examined in greater detail in paragraph 3.3.1 below.

\subsubsection{Award criteria}

The award stage of the procurement process incorporates a 90/10 and $80 / 20$ points system that is used to evaluate and award contracts. ${ }^{93}$ For contracts up to a value of R1 million, 80 points are allocated for price and 20 points for BBBEE criteria and for contracts over R1 million, 90 points are allocated for price and 10 points for BBBEE criteria. Depending on the value of the contracts, suppliers are awarded points out of 80 or 90 for price, and they are awarded points out of 20 or 10 for BBBEE criteria. The supplier who scores the highest total score out of 100 is then awarded the contract. Of particular note is that no express provision is made for the allocation of points other than on the basis of price and BBBEE criteria. The score that a supplier obtains for BBBEE criteria is presently tied to certain core elements that are laid down in the Codes of Good Practice on Black Economic Empowerment, ${ }^{94}$ ie ownership, management control, skills development, enterprise and supplier development, and socioeconomic development. ${ }^{95}$ No mention is made of innovation.

The PPPFA and Regulations do, however, provide for the award of a contract to a supplier who does not score the highest total points on the basis of price and BBBEE criteria if "objective criteria" are present to justify such an award. ${ }^{96}$ This is, in other words, the exception for the award of a contract to a supplier who does not score the highest total points. The question, therefore, is whether functionality criteria and more specifically innovation-related functionality criteria could serve as "objective criteria" to justify the award a contract to a supplier who does not score the highest total points. The High Court in the case of Rainbow Civils CC v Minister of

\footnotetext{
93 See s 2(1) of the PPPFA and Regulations 5 and 6 of the PPPFA Regulations.

94 Gen N 1019 in GG 36928 of 11 October 2013 (Codes of Good Practice).

95 Para 8.1 of the Codes of Good Practice.

96 See s 2(1)(f) of the PPPFA and Regulation 7(1) of the PPPFA Regulations.
} 
Transport and Public Works, Western Cape ${ }^{97}$ decided in 2013 that functionality criteria must play a role also after the award of points for price and preference. In other words, functionality criteria must serve as both qualification and award criteria. The court held that even though the general rule is that a contract must, in terms of the legislation, be awarded to the highest scoring bidder on the basis of price and preference, functionality criteria may serve as "objective criteria" for the award of a contract to a bidder other than the highest scoring one. The court relied specifically on section $2(1)(f)$ of the PPPFA.

As argued elsewhere ${ }^{98}$ even though section 2(1)(f) of the PPPFA provides for the award of a contract to a supplier other than the highest scoring one, the "objective criteria" that may justify such an award are highly constrained. The 2011 PPPFA Regulations are very precise on the award of points for preference. The manner in which functionality criteria have further been provided for in the Regulations does not qualify them as "objective criteria" for the purposes of section 2(1)(f). From the Regulations it is clear that pre-disclosed functionality criteria can justify the award of a contract to a bidder who does not score the highest points only if two bidders score equally for price and BBBEE criteria. ${ }^{99}$ This would then be the only instance where a supplier who scores high for functionality stands a chance of winning the contract on the basis of its functionality score. Moreover, unless innovation-related criteria were specifically communicated to suppliers as a functionality criterion, they cannot play any role during the award stage. Under the present PPPFA regime, therefore, functionality, and hence innovation-related criteria that are used as functionality criteria, can as a general rule play a role only as qualification criteria. Subject to the exception mentioned, they may not play any role during the award stage.

Insofar as price is concerned, it is important to bear in mind that more often than not innovative products are more costly in terms of their initial price. It is important therefore to take into account not only the price of the respective suppliers, but the total life-cycle cost, running costs and maintenance costs when evaluating different offers during the award stage. Allocating the highest points for price to the offer priced the lowest is therefore not an option when procuring innovative goods or services. The notion of "value for money" should thus not be equated with the

97 Rainbow Civils CC v Minister of Transport and Public Works, Western Cape 2013 ZAWCHC 3 (6 February 2013).

98 Bolton 2014 Speculum Juris 1-26.

99 See Regulation 11(5)(b) of the PPPFA Regulations. 
lowest priced offer, but instead with "procurement on the best available terms". 100 Value for money also means that the supplier is "able to provide what is required on the terms agreed". ${ }^{101}$ The supplier must be able to "offer" as well as "deliver". 102 In this respect the PPPFA and Regulations will serve as a barrier to the procurement of innovation, as reference is made simply to the "price" offered by suppliers without indicating whether this includes life-cycle costs, running costs and maintenance costs.

\subsubsection{Contract performance conditions}

An analysis of the legislation shows that no express provision is made for the inclusion of innovation-related contract performance conditions when procuring entities conclude contracts with winning suppliers. This does not, of course, deter procuring entities from doing so. Non-compliance with the conditions would then result in breach of contract. In the EU innovation-related contract performance conditions must be linked to the subject-matter of the contract. The innovation condition must, in other words, have an impact on the process of performance under the contract. ${ }^{103}$ In the South African context, it would appear that this need not necessarily be the case. In terms of the current legislative framework suppliers are, for example, awarded points for BBBEE criteria even though such criteria do not relate directly to the subject-matter of the contract. Innovation-related performance conditions could therefore be directly tied to the subject-matter of the contract or not. It would, however, still be important to inform suppliers beforehand that innovation-related performance conditions may or will be incorporated into the contract concluded with the winning supplier. This is, in turn, will require of procurement personnel to have the necessary expertise and knowledge, which factor is examined in greater detail in paragraph 3.3.1 below.

\subsection{Other barriers and possible solutions}

As is the case in most developing countries, there are a number of challenges that procuring entities in South Africa face when confronted with regular procurement, in other words, the procurement of ready-made and off-the-shelf items that do not require significant or any R\&D. An examination of these challenges falls outside the scope of this paper. The focus in this paragraph will instead be on those challenges or barriers that

\footnotetext{
100 See Arrowsmith, Linarelli and Wallace Regulating Public Procurement 29.

101 Arrowsmith, Linarelli and Wallace Regulating Public Procurement 30.

102 Arrowsmith, Linarelli and Wallace Regulating Public Procurement 30.

103 See art 70 of the EU Public Procurement Directive.
} 
will directly impact on and hinder the use of procurement to drive innovation.

\subsubsection{Lack of knowledge, skills and capacity}

A drawback in the South African system that will hinder the use of procurement to drive innovation is the lack of skills and capacity / lack of knowledge and capabilities on the part of procurement personnel. ${ }^{104}$ Even the procurement of off-the-shelf items, in other words, goods that are readily available and comparable in the market, currently suffers from a lack of proper knowledge, skills and capacity. The National Treasury has indicated that plans are underway to professionalise the procurement function of procuring entities, but at present (13 June 2016) public procurement and in particular the legal aspects of the procurement function receive very little attention at tertiary level. It is clear that that there is a dire need for procurement personnel to obtain practical experience and expertise to procure off-the-shelf items and also innovative products and services. Ambe and Badenhorst-Weiss ${ }^{105}$ succinctly point out that:

[t]o fully achieve SCM [supply chain management] objectives, the National Treasury provides support by facilitating the development of appropriate training materials to government departments, municipalities and municipal entities (National Treasury, 2005). However, the shortage of skills has been a re-concurrent theme in public discussion. According to Sheoraj (2007), skills and capacity shortages have been identified as the single greatest impediment to the success of public procurement in South Africa. Adequate capacity in the form of appropriate structures with fully skilled and professional SCM personnel is a key success factor for proper SCM implementation. In some government entities, the quality of SCM personnel's skills and ability are well below standard. Migiro and Ambe (2008) assert that many SCM actors in the South African public sphere have attended a number of training workshops on SCM, but they still lack the appropriate knowledge for proper implementation. McCarthy (2006) contends that there is a lack of capacity and knowledge by SCM actors to handle procurement processes that have led to bad governance. The South African government embarks on programmes that educate practitioners, but implementation of its programmes always falls short. ${ }^{106}$

104 Also see Georghiou et al 2010 https://www.escholar.manchester.ac.uk/api/data stream?publicationPid=uk-ac-man-scw:217123\&datastreamld=FULL-TEXT.PDF 8.

105 Ambe and Badenhorst-Weiss 2012 JTSCM 250.

106 Also see Kraemer-Mbula date unknown http:/www.cgee.org.br/eventos/arquivos/ BRICS-Erika_Mbula1.pdf. The author lists the following shortcomings that hinder the procurement of innovations: "great policies, [but] poor implementation and alignment with broader policy objectives; knowledge, skills and capacity; monitoring and evaluation - no common system data capturing systems; public and private corruption ... poor alignment between social goals and innovation goals ... [and] insufficient participation of stakeholders in [the public procurement] process". Ambe 
The authors also note that:

[i]nstitutions of higher learning and other service providers have a critical role to equip learners and practitioners with appropriate skills and knowledge. The capacity for qualified practitioners would only be available when educational institutions contribute to the challenge by way of developing a curriculum that meets the needs of the country. Such programmes should provide for an understanding of the knowledge of the South African public sector and its regulations. ${ }^{107}$

It is suggested, therefore, that the training of procurement personnel receive urgent attention to facilitate the efficient and cost-effective procurement of ready-made products as well as innovative goods and services. Procurement personnel would have to receive training on how to identify the various needs of a procuring entity as well as how to identify pressing societal problems to enable them to procure innovative goods.

\subsubsection{Lack of suppliers who are able to deliver}

The availability of suppliers who are able to offer and supply innovative solutions may be an obstacle in South Africa. The supplier base in South Africa may, in other words, be small, resulting in too low a level of competition that may reduce the incentive to innovate. Small firms may also lack the necessary resources to innovate. ${ }^{108}$ This does not, however, mean that the South African government should close the door on the use of procurement as a tool to drive innovation. In those instances where the necessary supplier base is lacking, international suppliers may have to be approached. The condition, however, should be that the winning international supplier involve local suppliers in the implementation of the awarded contract with the aim of transferring knowledge and expertise to the local supplier base.

\subsubsection{General obstacles}

Other obstacles that are of a more general nature, but that will also impact on the use of procurement to drive innovation, include the problem of

and Badenhorst-Weiss 2012 JTSCM 242-261 also identify other more general challenges to the procurement system, ie non-compliance with supply chain management policy and regulations; inadequate planning and the linking of demand to the budget; lack of accountability; fraud and corruption; inadequate monitoring and evaluation of supply chain management; unethical behaviour; too much decentralisation of the procurement system; and ineffectiveness of the BEE policy.

107 Ambe and Badenhorst-Weiss 2012 JTSCM 254-255.

108 See for example Georghiou et al 2010 https://www.escholar.manchester.ac.uk/ api/datastream?publicationPid=uk-ac-man-scw:217123\&datastreamld=FULL-

TEXT.PDF 8. 
procurement corruption, potential difficulties in relation to the safeguarding of the security of intellectual property, and the current lack of joint action and collaboration amongst procuring entities. A 2014 report of the AuditorGeneral, for example, found that the unauthorized expenditure of public funds amounted overall to R2.9-billion per year and irregular expenditure to a staggering R28.3-billion, while fruitless and wasteful expenditure rose to almost R1.8-billion. ${ }^{109}$ There is clearly a dire need to ensure the effective and efficient use of public funds in South Africa. If suppliers are going to be approached by the government to invent new and innovative products, it is also imperative for the necessary measures to be in place to ensure that security is provided for intellectual property. As noted in paragraph 3.2.3 above, the protection of confidential information is adequately provided for in the context of unsolicited offers. Insofar as joint action and collaboration amongst procuring entities are concerned, it is submitted that there is a need for research to be conducted into the procurement practices of state-owned enterprises (SOEs) in South Africa in particular, with a view to determining whether these entities procure innovative products and services and the manner in which they do so. Collaboration amongst procuring entities in South Africa will go a long way to ensuring that innovative procurement becomes a reality.

\section{$4 \quad$ Concluding remarks}

It is clear that there are a number of regulatory as well as non-regulatory obstacles that currently hinder South Africa's use of public procurement to drive innovation. An examination of South Africa's public procurement regulatory regime makes clear that even though section 217 and in particular section 217(2)(a) of the Constitution leaves scope for the promotion of innovation in procurement, limited provision is made in the legislation for the role that innovation should or could play in the procurement function of the government. It is clear that of primary importance is the promotion of BBBEE. The procurement legislation is generally silent on the use of procurement to drive innovation.

South Africa's current use of procurement to address past apartheid policies and practices is clearly commendable. However, given the growing international demand / trend to link procurement to innovation, and moreover the need to improve the quality and efficiency of public service delivery in South Africa and address the country's socio-economic

109 Malunga 2014 http://www.pprotect.org/docs_publications/PAPER\%20DPP\%20 STATE\%20CONTRACTS_TENDERS.pdf 4. 
challenges, it is important for procuring entities to use procurement also as a tool to drive innovation. ${ }^{110}$ At present there is limited scope within the legal regime for such use, but it has been shown that there are ways in which the current barriers can be addressed, which would in turn increase the potential for innovative procurement practices.

There are, moreover, two non-procurement-related policy documents that recognise the importance that public procurement can play in fostering innovation, which serve as an indication that perhaps there is light at the end of the tunnel. The 2014 Industrial Policy Action Plan (IPAP 2014) ${ }^{111}$ issued by the government, for example, stipulates that "'[g]overnment has significant purchasing power that it can use to stimulate economic development and industrial innovation and transform public services". ${ }^{112}$ In the Ten-Year Innovation Plan for 2008-2018 of the Department of Science and Technology ${ }^{113}$ also the link between public procurement and innovation is recognised as an area that requires urgent attention. Most relevant is that the plan identifies five "grand challenges" ie the Farmer to Pharma value chain to strengthen the bio-economy (the aim being for South Africa to become a world leader in biotechnology), space science and technology (South Africa should be an important contributor to global space science and technology), energy security, global-change science with a focus on climate change, and human and social dynamics. ${ }^{114}$ The Plan then makes explicit mention inter alia of the role that public procurement can play to stimulate innovation. It is stated that:

[t]he government recognizes the potential to make use of procurement to stimulate technological innovation. The challenge is to develop a public procurement regulatory framework that supports local innovations, including SMMEs and technology start-ups. ${ }^{115}$

110 For information on the state of service delivery in South Africa, see Empowerdex 2009

http://www.empowerdex.co.za/Portals/5/docs/Press\%20releases/citydex_report.pdf. See also Grant 2014 http://mg.co.za/article/2014-02-12-research-shows-sharpincrease-in-service-delivery-protests; Kraemer-Mbula date unknown http://www.cgee.

org.br/eventos/arquivos/BRICS-Erika_Mbula1.pdf.

111 dti Industrial Policy Action Plan.

112 dti Industrial Policy Action Plan 42.

113 DST Knowledge-Based Economy.

114 DST Knowledge-Based Economy 11.

115 DST Knowledge-Based Economy 32. 


\section{Bibliography}

\section{Literature}

Ambe and Badenhorst-Weiss 2012 JTSCM

Ambe IM and Badenhorst-Weiss $\mathrm{J}$ "Procurement Challenges in the South African Public Sector" 2012 JTSCM 242-261

Angel and Blay 2014 Eur Procurement \& Pub Private Partnership L Rev Angel M and Blay B "The Strategic Use of Public Procurement in Support of Innovation" 2014 Eur Procurement \& Pub Private Partnership L Rev 311

Arrowsmith and Kunzlik Social and Environmental Policies Arrowsmith S and Kunzlik PF (eds) Social and Environmental Policies in EC Procurement Law: New Directives and New Directions (Cambridge University Press Cambridge 2009)

Arrowsmith and Nicholas "UNCITRAL Model Law on Procurement" Arrowsmith $S$ and Nicholas $C$ "The UNCITRAL Model Law on Procurement: Past, Present and Future" in Arrowsmith S (ed) Reform of the UNCITRAL Model Law on Procurement (Thomson Reuters/West 2009) ch 1

Arrowsmith, Linarelli and Wallace Regulating Public Procurement Arrowsmith S, Linarelli J and Wallace D Jr Regulating Public Procurement: National and International Perspectives (Kluwer Law International The Hague 2000)

Audet 2002 OECD Journal on Budgeting

Audet D "Government Procurement: A Synthesis Report" 2002 OECD Journal on Budgeting 149-194

Bolton 2004 SALJ

Bolton P "The Use of Government Procurement as an Instrument of Policy" 2004 SALJ 619-635

Bolton 2006 Stell LR

Bolton P "Scope for Negotiating and / or Varying the Terms of Government Contracts Awarded by Way of a Tender Process" 2006 Stell LR 266-288

Bolton Government Procurement in South Africa

Bolton P The Law of Government Procurement in South Africa (LexisNexis Butterworths South Africa 2007) 
Bolton 2008 TSAR

Bolton P "Incorporating Environmental Considerations into Government Procurement in South Africa" 2008 TSAR 31-51

Bolton "Regulatory Framework for Public Procurement" Bolton $\mathrm{P}$ "The Regulatory Framework for Public Procurement in South Africa" in Quinot G and Arrowsmith S (eds) Public Procurement Regulation in Africa (Cambridge University Press Cambridge 2013) ch 9

Bolton 2014 Speculum Juris

Bolton P "An Analysis of the Criteria Used to Evaluate and Award Public Tenders" 2014 Speculum Juris 1-26

Bolton and Quinot "Social Policies in Procurement"

Bolton $P$ and Quinot $G$ "Social Policies in Procurement and the Government Procurement Agreement: A Perspective from South Africa" in Arrowsmith S and Anderson RD (eds) The WTO Regime on Government Procurement: Recent Developments and Challenges Ahead (Cambridge University Press Cambridge 2011) ch 16

Bright Public Procurement Handbook

Bright C Public Procurement Handbook (Chancery Law Colorado Springs, CO 1994)

Caranta and Trybus Green and Social Procurement

Caranta R and Trybus M (eds) The Law of Green and Social Procurement in Europe (DJQF Publishing Copenhagen 2010)

De la Harpe Public Procurement Law

De la Harpe S Public Procurement Law: A Comparative Analysis (LLDthesis University of South Africa 2009)

DST Knowledge-Based Economy

Department of Science and Technology A Knowledge-Based Economy: Ten Year Plan for South Africa (2008-2018) (DST Pretoria 2007)

dti Industrial Policy Action Plan

Department of Trade and Industry Industrial Policy Action Plan: Economic Sectors and Employment Cluster IPAP 2014/2015-2016/2017 (dti Pretoria 2014) 
Edquist and Zabala-Iturriagagoitia 2012 Research Policy

Edquist $\mathrm{C}$ and Zabala-Iturriagagoitia JM "Public Procurement for Innovation as Mission-oriented Innovation Policy" 2012 Research Policy 1757-1769

Hommen and Rolfstam 2009 JOPP

Hommen $L$ and Rolfstam M "Public Procurement and Innovation: Towards a Taxonomy" 2009 JOPP 17-56

Lember, Kattel and Kalvet Public Procurement

Lember V, Kattel R and Kalvet T (eds) Public Procurement, Innovation and Policy: International Perspectives (Springer Heidelberg 2014)

McCrudden Buying Social Justice

McCrudden C Buying Social Justice: Equality, Government Procurement and Legal Change (Oxford University Press Oxford 2007)

National Treasury Practice Note SCM 2

National Treasury Practice Note Number SCM 2 of 2005: Supply Chain Management (National Treasury Pretoria 2005)

National Treasury Practice Note 11

National Treasury Practice Note No 11 of 2008/2009: Unsolicited Proposals (National Treasury Pretoria 2009)

Nicholas 2012 PPLR

Nicholas C "The 2011 UNCITRAL Model Law on Public Procurement" 2012 PPLR 111-123

OECD Demand-side Innovation Policies

Organisation for Economic Co-operation and Development Demand-side Innovation Policies (OECD Paris 2011)

OECD Reviews of Innovation Policy

Organisation for Economic Co-operation and Development Reviews of Innovation Policy: Mexico (OECD Paris 2009)

Penfold and Reyburn "Public Procurement"

Penfold $\mathrm{G}$ and Reyburn $\mathrm{P}$ "Public Procurement" in Chaskalson $\mathrm{M}$ et al (eds) Constitutional Law of South Africa $2^{\text {nd }}$ ed (Juta Cape Town 2002) ch 25 
Quinot "Promotion of Social Policy"

Quinot G "Promotion of Social Policy Through Public Procurement in Africa" in Quinot $\mathrm{G}$ and Arrowsmith S (eds) Public Procurement Regulation in Africa (Cambridge University Press Cambridge 2013) ch 15

Quinot 2014 PER/PELJ

Quinot G "The Role of Quality in the Adjudication of Public Tenders" 2014 PER/PELJ 1110-1136

Rolfstam Public Procurement and Innovation

Rolfstam M Public Procurement and Innovation: The Role of Institutions (Edward Elgar Cheltenham 2013)

\section{Case law}

Rainbow Civils CC v Minister of Transport and Public Works, Western Cape 2013 ZAWCHC 3 (6 February 2013)

\section{Legislation}

Broad-Based Black Economic Empowerment Act 53 of 2003

Constitution of the Republic of South Africa, 1996

Local Government: Municipal Finance Management Act 56 of 2003

Preferential Procurement Policy Framework Act 5 of 2000

Public Finance Management Act 1 of 1999

\section{Government publications}

GN 225 in GG 27388 of 15 March 2005 (Treasury Regulations for Departments, Trading Entities, Constitutional Entities and Public Entities)

Gen N 868 in GG 27636 of 30 May 2005 (Municipal Finance Management Act, 2003: Municipal Supply Chain Management Regulations)

GN 502 in GG 34350 of 8 June 2011 (Preferential Procurement Regulations / PPPFA Regulations)

Gen N 1019 in GG 36928 of 11 October 2013 (Codes of Good Practice) 


\section{International instruments}

Directive 2014/23/EU of the European Parliament and of the Council of 26 February 2014 on the Award of Concession Contracts

Directive 2014/24/EU of the European Parliament and of the Council of 26 February 2014 on Public Procurement and Repealing Directive 2004/18/EC

Directive 2014/25/EU of the European Parliament and of the Council of 26 February 2014 on Procurement by Entities operating in the Water, Energy, Transport and Postal Services Sectors and Repealing Directive 2004/17/EC

UNCITRAL Model Law on Public Procurement (2011)

\section{Internet sources}

AFP 2013 http://www.news24.com/Africa/News/Africas-unemploymentfigures-frightening-20131121

AFP 2013 "Africa's Unemployment Figures Frightening" http://www.news24.com/Africa/News/Africas-unemployment-figuresfrightening-20131121 accessed 3 June 2016

dti 2016 http://www.dti.gov.za/industrial_development/ip.jsp Department of Trade and Industry 2016 Industrial Procurement http://www.dti.gov.za/industrial_development/ip.jsp accessed 6 June 2016

Empowerdex 2009 http://www.empowerdex.co.za/Portals/5/docs/Press\% 20releases/citydex_report.pdf

Empowerdex 2009 Service Delivery Index (Citydex) Report http://www.empowerdex.co.za/Portals/5/docs/Press\%20releases/citydex_r eport.pdf accessed 3 June 2016

EU 2014 http://ec.europa.eu/internal_market/publicprocurement/docs/ modernising_rules/reform/fact-sheets/fact-sheet-09-innovation_en.pdf European Union 2014 Public Procurement Reform: Fact Sheet 9 http://ec.europa.eu/internal_market/publicprocurement/docs/modernising_r ules/reform/fact-sheets/fact-sheet-09-innovation_en.pdf accessed 9 June 2016

EU Project OMC-PTP 2009 http://de.koinno-bmwi.de/system/ publications/files/000/000/040/original/Exploring_public_procurement_as_ a_Strategic_Innovation_Policy_Mix_Instrument.pdf?1372758315 
EU Project OMC-PTP 2009 Exploring Public Procurement as a Strategic Innovation Policy Mix Instrument http://de.koinno-bmwi.de/ system/publications/files/000/000/040/original/Exploring_public_procurem ent_as_a_Strategic_Innovation_Policy_Mix_Instrument.pdf?1372758315 accessed 9 June 2016

Georghiou et al 2010 https://www.escholar.manchester. ac.uk/api/datastream?publicationPid=uk-ac-man-scw:217123\&datastream Id=FULL-TEXT.PDF

Georghiou L et al 2010 Public Procurement for Innovation in Small European Countries https://www.escholar.manchester.ac.uk/api/data stream?publicationPid=uk-ac-man-scw:217123\&datastreamld=FULL-

TEXT.PDF accessed 10 June 2016

Grant 2014 http://mg.co.za/article/2014-02-12-research-shows-sharpincrease-in-service-delivery-protests

Grant L 2014 Research Shows Sharp Increase in Service Delivery Protests http://mg.co.za/article/2014-02-12-research-shows-sharpincrease-in-service-delivery-protests accessed 10 June 2016

Kattel and Lember 2010 http://hum.ttu.ee/wp/paper31.pdf Kattel R and Lember V 2010 Public Procurement as an Industrial Policy Tool - An Option for Developing Countries? Presentation at International Public Procurement Conference, 26-28 August 2010, Seoul, Korea https://prezi.com/mbsaaynp_w_p/public-procurement-as-an-industrialpolicy-tool-an-option-for-developing-countries/ accessed 13 June 2016

Kraemer-Mbula date unknown http://www.cgee.org.br/eventos/ arquivos/BRICS-Erika_Mbula1.pdf

Kraemer-Mbula E date unknown Public Procurement and Innovation in a South African Context - Presented at the BRICS Seminar: Systems of Innovation and Development, Brasilia, March 25th-27th http://www.cgee.org.br/eventos/arquivos/BRICS-Erika_Mbula1.pdf acces sed 3 June 2016

Malunga 2014 http://www.pprotect.org/docs_publications/PAPER\%20DPP $\% 20 S T A T E \% 20 C O N T R A C T S \_T E N D E R S . p d f$

Malunga K 2014 The Office of the Public Protector and State Contracts / Tenders - A Discussion of Jurisdiction and Remedies http://www.pprotect.org/docs_publications/PAPER\%20DPP\%20STATE\%2 OCONTRACTS_TENDERS.pdf accessed 3 June 2016 
National Treasury 2005 http://mfma.treasury.gov.za/MFMA/Guidelines/ Guide\%20for\%20Municipal\%20Accounting\%200fficers_1.pdf

National Treasury 2005 Supply Chain Management: A Guide for Accounting Officers of Municipalities and Municipal Entities http://mfma. treasury.gov.za/MFMA/Guidelines/Guide\%20for\%20Municipal\%20Account ing\%20Officers_1.pdf accessed 3 June 2016

National Treasury 2016 http://www.treasury.gov.za

National Treasury 2016 Home Page http://www.treasury.gov.za 3 June 2016

Sanchez-Graells 2015 http://www.howtocrackanut.com/blog/2015/04/inno vation-partnerships-under-reg-31.html?rq=innovation\%20partnership Sanchez-Graells A 2015 Innovation Partnerships under Regulation 31 Public Contracts Regulations 2015 http://www.howtocrackanut.com/ blog/2015/04/innovation-partnerships-under-reg-31.html?rq=innovation \%20partnership accessed 6 June 2016

Scott 2016 http://www.cips.org/supply-management/news/2016/february/ south-africa-to-reform-public-procurement-processes/

Scott A 2016 South Africa Reforms Public Procurement to Save R25bn http://www.cips.org/supply-management/news/2016/february/south-africato-reform-public-procurement-processes/ accessed 9 June 2016

Semple date unknown https://www.innovation-procurement.org/fileadmin/ editor-content/Guides/PPI-Platform_Guide_new-final_download.pdf Semple A (ed) date unknown Guidance for Public Authorities on Public Procurement of Innovation https://www.innovation-procurement.org/file admin/editor-content/Guides/PPI-Platform_Guide_new-final_download.pdf accessed 6 June 2016

Trading Economics 2016 http://www.tradingeconomics.com/southafrica/unemployment-rate

Trading Economics 2016 South Africa Unemployment Rate 2000-2016 http://www.tradingeconomics.com/south-africa/unemployment-rate accessed 9 June 2016

\section{List of Abbreviations}

BBBEE

BEE

DST

dti
Broad-Based Black Economic Empowerment Black economic empowerment Department of Science and Technology Department of Trade and Industry 


\begin{tabular}{|c|c|}
\hline EU & European Union \\
\hline Eur Procurement \& Pub & European Procurement and Public \\
\hline Private Partnership L Rev & Partnership Law Review \\
\hline GDP & Gross domestic product \\
\hline IPAP & Industrial Policy Action Plan \\
\hline JOPP & Journal of Public Procurement \\
\hline JTSCM & $\begin{array}{l}\text { Journal of Transport and Supply Chain } \\
\text { Management }\end{array}$ \\
\hline MFMA & $\begin{array}{l}\text { Local Government: Municipal Finance } \\
\text { Management Act }\end{array}$ \\
\hline OECD & $\begin{array}{l}\text { Organisation for Economic Cooperation and } \\
\text { Development }\end{array}$ \\
\hline PER/PELJ & $\begin{array}{l}\text { Potchefstroomse Elektroniese Regstydskrif } \\
\text { Potchefstroom Electronic Law Journal }\end{array}$ \\
\hline PPfl & Public Procurement for Innovation \\
\hline PPI & Public Procurement of Innovation \\
\hline PFMA & Public Finance Management Act \\
\hline PPLR & Public Procurement Law Review \\
\hline PPP & Public-private partnership \\
\hline PPPFA & Preferential Procurement Policy Framework Act \\
\hline$R \& D$ & Research and development \\
\hline RFP & Request for Proposals \\
\hline RFQ & Request for Qualification \\
\hline SALJ & South African Law Journal \\
\hline SCM & Supply Chain Management \\
\hline SOEs & State-owned enterprises \\
\hline tell LR & Stellenbosch Law Review \\
\hline SAR & Tydskrif vir die Suid-Afrikaanse Reg \\
\hline
\end{tabular}

